\title{
Report from the Region
}

\section{The "Anti-Gender" Wave Contested: Gender Studies, Civil Society, and the State in Eastern Europe and Beyond*}

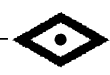

On 12 October 2018, without any public statement or explanation, the responsible Hungarian authorities removed the two-year MA degree program in gender studies, first accredited in Hungary in 2007 and overhauled in 2016, from the list of approved study programs. (Students currently enrolled in any such master's degree at any university in the country can finish their course of studies as usual.) For the MA degree program in gender studies established in 2017 at Eötvös Loránd University in Budapest, a state university and the largest university in terms of student numbers in the country, this equals abolition. For the two-year MA program in critical gender studies at Central European University (CEU) it means the loss of Hungarian accreditation, by which the degree was formally recognized in the European Union. This combines with the fact that CEU has lost the right to enroll new students into its US programs operated in Hungary, and more generally to operate in Hungary as an American institution (though this still is subject to legal encounters). Already in March 2017, at the time when the higher education reform was announced that would result in making CEU's continued operation in Hungary impossible, the government discussed a report on "a number of questions of the gender studies MA degree," and representatives of the small Catholic coalition partner of the government led by Viktor Orbán's Fidesz/ Hungarian Civic Alliance, the Christian Democratic People's Party, publicly denied the legitimacy of gender studies as an academic subject.

As a result of these combined developments, no student is in the position as of 2019 to apply for any graduate degree program in gender studies in Hungary any longer. This includes the CEU PhD program in comparative gender studies. The two-year MA program MATILDA European Master in Women's and Gender History, a cooperative degree program that involves several universities including CEU and Sofia University St. Kliment Ohridski in Bulgaria, similarly has lost its Hungarian accreditation. The only exception are Erasmus Mundus Joint Master Degrees such as the GEMMA Master's Degree in Women's and Gender Studies. All other gender studies programs at CEU will be taught, for the time being as US-accredited degree programs or as programs accredited in Austria through the newly accredited CEU Austria Private University, in Austria (and incoming students will also be enrolled into various graduate non-degree programs accredited via KEE, the Hungarian sister entity of CEU). ${ }^{1}$ 
The Hungarian episode ${ }^{2}$ epitomizes and spearheads a political development that carries much larger relevance in four senses. First, there is a trend to question the raison d'être of institutions and politics that, in the first place, were established based in feminist insight, knowledge, and perspective, and consequently to undermine the relevant policies, cut funding for related institutions, project lines, and cut back or abolish - as in the Hungarian case-academic programs and study modules. This is true even while in parallel we witness the emergence of the \#MeToo movement and new feminisms more generally. In other words, progressive gender politics rather than gender studies alone are put into question. Second, this trend is spreading around the world, with ever more governments, public campaigning, and vocal nongovernmental organizations (NGOs) in ever more countries joining in. Smaller and larger measures that curb gender studies and progressive gender politics are being implemented month by month or even day by day. The development of "anti-gender" policies, in other words, is global in character. Third, the trend has been based in an ingenious combination of reasoning. As a rule, it combines face-value adherence to progressive, or mainstreamed, gender norms, such as equal treatment or politics against sexualized gender violence on the one hand, with aggressive attacks on "gender ideology" or its supposedly extremely harmful "exaggerations" (e.g., confusion of the gender identity of kindergarten children), similarly aggressive anti-immigration discourse or anti-Muslim racism in particular and aggressive responses to other feminist discourses and policies, on the other. Fourth, as this dual "argument" unfolds we witness, in parallel, the incessant transgression of the inherited boundaries of acceptable public speech (about women, migrants, reproductive rights, etc.). The dual "argument" in many places has facilitated the intrusion of the new "anti-gender" ideology into the societal mainstream, and has combined with blatant sexism and gendered racism, which have become-once again - socially acceptable.

The abolition of institutionalized (graduate) gender studies degree programs at Hungarian universities needs to be read against this overall global trend and placed into the context of related developments in other Central Eastern European countries. The official argument by which the Hungarian authorities justified the abolition of the two-year MA degree in gender studies, namely, lack of interest, is a blatant lie. In the last decade approximately twenty students graduated per year from the Hungarianaccredited two-year MA program at CEU, and those enrolled have been selected from among 150 to 200 applicants every year. The repercussions in Hungarian academe of the decision to abolish the MA degree remain to be seen. How will university deans and other authorities engage with - still-existing specializations in gender studies, with requests for new gender studies modules to be established, with the teaching interests of individual scholars, and conference plans pursued in the community? How will the gender studies community and its individual members persevere or accommodate in terms of designing, presenting, and pursuing their research and teaching interests?

The scholarly activities and decisions of all of these actors unfold against a pervasive "anti-gender" atmosphere and discourse sustained by dominant political actors and media in the country. In this context, gender studies scholars and some academic managers have played an important role in sustaining an alternative academic discourse and a counter public more generally. There is a large and highly visible com- 
munity in Hungary of gender studies scholars and scholars fully dedicated to generate knowledge and teach courses focused on gender. Important initiatives and institutions include the Center for Gender and Cultural Studies, codirected by Miklós Hadas and Beata Nagy, at Corvinus University in Budapest, the Gender Studies Research Group at the English Department of the University of Szeged, and the electronic journal Társadalmi Nemek Tudománya: Interdiszciplináris eFolyóirat (Gender science: Interdisciplinary e-journal) with Erzsébet Barát as editor in chief.

In other Central Eastern and Southeastern European countries the new "antigender" politics have made themselves felt to variable degrees. Direct interventions against institutionalized gender studies programs so far have been the exception rather than the rule. However, in many places there have been highly publicized broader "anti-gender" campaigns, and their promoters have been ingenious in construing various "incidents" as triggers for their crusades. Everywhere, "anti-gender" politics confront vibrant gender studies communities and have given rise to scholarly and activist responses. In this report we aim to give up-to-date information describing this state of affairs in Central Eastern and Southeastern Europe in the hope to contribute to the development of both a global consciousness and action in support of gender studies.

Serbia has not witnessed any formalized institutional intervention aimed at curbing the academic study of gender. The viability and continued existence of the oneyear MA program in political science/gender studies at the University of Belgrade and the doctoral program in gender studies at the University of Novi Sad have depended on the number of the applicants. If insufficient numbers of students apply-and there might be such a trend in recent years - these programs cannot function properly. With the two programs mentioned, as well as other initiatives and institutions, gender studies have been in working order in the country in recent years. One successful collaborative project emerged from the doctoral seminar "Bringing Theory, Activism and Cultural Practices Together: Feminist Press in Serbia in the 1990s and 2000s," taught at the Faculty of Philology of the University of Belgrade over two years. The seminar resulted in the publication of the volume The Feminist Press in Serbia: Theory, Activism and Art Practices in the 1990s and 2000s, edited by Ana Kolarić and Biljana Dojčinović, which brings together contributions by the lecturers and the participants. ${ }^{3}$ The seminar as well as the publication received support through a competitive international funding line. ${ }^{4}$

The Center for Women's Studies in Zagreb, Croatia, has been functioning well in scholarly and activist terms, yet with growing financial difficulties in recent years. In 2018, the journal Treća (The [female] third), established twenty years ago, and to date the only feminist journal in Croatia, has not received funding from any municipal or state institution. As this Aspasia editorial goes to press, the editors of the journal, which is published by the Center for Women's Studies in Zagreb, are still busy in a completely unpaid capacity to prepare the publication of the twentieth anniversary issue. The editor in chief, Nataša Govedić, in her introduction to this forthcoming issue, discusses this problem in the context of the withdrawal of funding from many important media in Croatia.

In Slovenia the academic study of gender is not as such subject of public critique, yet there has been aggressive public pillorying of individual researchers and profes- 
sors. In March 2018, a Slovenian right-wing television station and a Christian fundamentalist online magazine attempted to stir up public outrage against a group of graduate social work students enrolled in an MA program in social work known for its gender and human rights orientation at the University of Ljubljana. The incident happened after the students returned from fieldwork in Serbia, where they worked with refugees living in a "jungle" settlement. The vitriolic diatribes were wrapped in a language of care, expressing concern for "our girls":

See what the Faculty of Social Work does with their students! . . They sent the female students to entertain migrants ... Does the Faculty of Social Work not find any other example of human suffering, a homeless, an elderly or abandoned person, along with whom the future social workers could develop empathy? According to our source, the empathy of the future social workers to "young, good-looking men with white teeth" went so far that during their stay some of them fell in love with migrant men in the squat and now seek the way to return.

The public response was fast and copious, spreading anti-refugee propaganda and targeting human rights values promoted by critical social work. Scores of anonymous commentators in the comments section hardened the author's violence masked as coercive care. There was a torrent of hatred for social work students and social work educators; there were calls for sexually violating the "Muslim whores," "killing social work professors," and "closing down the faculty." The social work department was tagged as a "breeding place of leftists, homosexuals and feminists, who prefer to help the Muslim men rather than the Slovenian poor." 5

Taken together it might be argued that in both Serbia and Croatia the problems encountered by the institutions and infrastructures of gender studies in large measure are a result of wider neoliberal policies directed at the educational and cultural spheres, and the ever-decreasing investment of the state in these two areas. Just as in Hungary, so far this has not had a visible negative impact on the substantive academic and cultural work and activism on gender issues. However, the Slovenian incident signals that aggressive challenges to progressive gender values that have been present in the larger public sphere may easily spill over to the academic sphere. In 2012, the organization Croat Voice of Parents for Children, founded in 2006 to promote parents' right to educate their children in accord with the "Croatian value system," organized a campaign against the health education program in schools. The organization claimed that the inclusion of themes such as sexual diversity and reproductive rights is tantamount to sexualizing children and promoting homosexuality. ${ }^{6}$ In Ljubljana, since 2015, prayers for unborn children are regularly staged in front of the maternity hospital. In 2016, over 180 persons signed the appeal to stop the unconstitutional political action, among them many gender studies scholars (including Vlasta Jalušič, Mojca Dobnikar, Tanja Rener, Mirjana Ule, Milica Antić, Roman Kuhar, Vesna Leskošek, Ana Sobočan, Svetlana Slapšak, Darja Zaviršek, and others). The online media Kul.si, run by the church establishment, called the individuals who signed the petition "killers of unborn babies."7 A legal complaint against the allegations contained in Kul.si was 
unsuccessful. The court in 2019 ruled that there is not enough proof to sentence Kul.si for hate speech crime.

Gender studies as an academic discipline in Romania are not currently contested (at least not through any overt institutional interventions). There are gender studies courses and modules in all the major universities in Romania, mostly integrated in political science, sociology, anthropology, or literature departments. Two MA programs focused on gender issues are offered in Romania at the moment, both in Bucharest. These are the MA program in Policies, Gender and Minorities at the National School for Political Science and Administration, and the program Policies of Equal Opportunity in the Romanian and European Context, a Romanian-French MA program offered by the University of Bucharest. Gender studies programs offered by the public universities in Timișoara and Cluj from the early 2000 s folded several years ago.

Some existing gender studies programs seek to position themselves as producers of experts in EU gender policies. In the city of Cluj, a version of anti-racist intersectional feminism is becoming visible to the academic environment, largely through Eniko Vincze's action research on Romnja women's movements. ${ }^{8}$ Other gender studies academics in Romania are orienting themselves toward building a viable international research profile by joining or creating networks for advanced studies institutes, such as the Bucharest-based Centre Régional Francophone de Recherches Avancées en Sciences Sociales (Regional Francophone Center for Advanced Research in the Social Sciences). However, most of these programs and academics still have difficulties accessing European research funding, as the rules of the game in Romania do not match the publishing or promotion criteria orienting academia in Western Europe, sometimes resulting in dismissive evaluations by major funding bodies. The reaction so far is to adapt rather than reject these hierarchies.

Academic gender studies with a focus on violence against women, work-life balance, or women's formal political representation apparently cause no ideological trouble in Romania for now. One strategy seems to have been for institutionalized gender studies to fly under the radar of the "anti-gender" cultural and political trend, that is, institutionalized gender studies at times escaped challenges paradoxically because gender and sexuality were at the center of an opportunistically fomented "culture war" between the electorates of the governing Social-Democratic Party (PSD) - perceived internationally and by a significant, highly vocal, chunk of the electorate as corrupt and incompetent-and the pro-EU, anti-corruption, center-right president Klaus Iohannis. The PSD government-eager to shore up its base-tried to reach out for the Fidesz toolbox. Government media mentioned George Soros - founder of Central European University in Budapest, and main target of the Hungarian government's anti-immigration campaign - daily. On 8 March 2019, one of the most watched television channels in Romania, aligned with the PSD, broadcast a program on "feminism as a dangerous current." The show's argument was that it was possible to be a strong, complex woman without the dangerous politics of feminism. The broadcast signaled that government circles aimed to reach out for a new kind of gender-related public discourse that was meant to mobilize a more secular, less intensely nationalistic but still conservative middle-class public than what could be achieved through the discourses on the "traditional Romanian family" spearheaded by the government-allied 
Romanian Orthodox Church on the occasion of the "Referendum for the Family" in October 2018. That referendum, agitated for by a coalition of conservative nongovernmental organizations and agreed to by the PSD, was meant to enshrine heterosexual marriage in the country's constitution; it failed due to the lack of a quorum.

Despite attempts at pivoting toward mildly Euro-skeptic and even Christiandemocratic themes, the governing PSD party was nowhere near as popular as Fidesz in Hungary and did not achieve Fidesz's coherence of message. For instance, the PSD has been ambivalent even about their "pro-family" platform. While the referendum was being prepared, in March 2018, the PSD party leader proposed to Parliament a debate about the introduction of civil partnerships in Romanian legal practice. The proposal could be interpreted as an attempt at creating an opening to allow same-sex couples access to civil partnerships if same-sex marriage was prohibited. (This happened in Croatia after their successful pro-family referendum in 2013, implying the emergence of a regional model for appeasing the EU and compensating "the losers" of the referendum.) Also, the PSD prime minister delivered a pro-EU gender equality speech in Brussels on 7 March 2019. Yet at the same time President Iohannis positioned himself as more progressive than the PSD, seeing how the "Referendum for the Family" galvanized anti-PSD opposition. (Before October 2018, the president did not voice opposition to the idea if a "referendum for the family" yet briefly stated he was in favor of "tolerance.")

In this context, education for reproductive health/sexuality became the main site for the critique of "gender ideology" in Romania. There was growing opposition to adding sex education to the National Strategy for Education, and church opposition against having sex education as an optional subject in schools. Declining numbers of students opt for sex education in schools where it is offered (around 5 percent in 2018). In February 2019, President Iohannis, seeking to capitalize on the new alignment between anti-PSD and anti-referendum forces, launched the "Educated Romania" report outlining the president's long-term vision for education, which includes references to the importance of sex education.

Gender studies scholars have not only publicly reflected on the "anti-gender" ideology, and relevant developments more broadly, but engaged in organized protest. In particular, more critical versions of gender studies are practiced by scholars who do not (yet) have academic appointments or secure institutional affiliations. In November 2017 the conference "Queer and Feminist Studies in Eastern Europe" was held in Bucharest. ${ }^{9}$ The journal ANAlize: Journal of Gender and Feminist Studies (re-established in 2013), in its October 2018 issue, published several articles on LGBT activism and conservative backlash. ${ }^{10}$ In February 2018 an "Open Letter by Academics Concerning the Problematics of Gender Equality" was published. ${ }^{11}$ The open letter requested recognition for "gender experts" trained through the gender studies MA programs in Romania and the inclusion of "gender equality experts" on the roster of recognized jobs in Romania. It decried the training of four thousand persons through a government program on the basis of a curriculum that was not public and had not been created through consultations with any of the recognized academic experts in the field. The letter demanded the introduction of a requirement that for all gender equalityrelated positions in central institutions, a gender studies MA diploma and experience 
in feminist NGOs should be a minimum requirement in order to avoid "imposture and amateurism" and promote the "common objective of gender equality and equal opportunities in the political and social space in Romania." ${ }^{12}$

In Bulgaria, the MA program in gender studies of Sofia University St. Kliment Ohridski at present practically has ceased to be operative mainly due to generational change. ${ }^{13}$ However, a group of scholars including historian Krassimira Daskalova, cultural studies scholar Daniela Koleva, and literary studies scholar Miglena Nikolchina at present are energetically working to revive the program. They do so amid a strong current of "anti-gender" discourse and action that has swamped the public sphere in the country. ${ }^{14}$ The most recent incident concerns the collaboratively designed project proposal entitled "Forum for a Gender Balanced Model at School: The Bulgarian Case," submitted to the 2018/2019 Participation Program of UNESCO, which had invited applications in the thematic area of gender and education. The project passed the first round and was sent to the final selection procedure in Paris. However, one of the right-wing advisers of the Bulgarian president began to engage in a campaign against the "gender ideology" contained in the proposal, and the minister of education appeared in the media saying that even if the project was successful, he would not allow it to enter Bulgarian schools. In the media, the research team was labeled "gender agents," corrupt, evil, and so forth. ${ }^{15}$ At this point a few individuals belonging to academic circles began to speak out against "gender ideology" too. The Ministry of Education and the Bulgarian Academy of Sciences reassured society that gender studies will not be developed in their agenda.

The incident came after the ground had been prepared by a campaign against the ratification of the Council of Europe Convention on preventing and combating violence against women and domestic violence (often called the "Istanbul Convention"), which began in December 2017. This campaign in a unique manner used "antigender" ideology to delegitimize progressive gender politics as such. The leader of the nationalist party VMRO, Krassimir Karakachanov, who is also a vice-premier minister and a minister of defense, issued a press release entitled, "VMRO: Bulgaria, Pressed by International Lobbyists to Legalize the Third Sex."16 Karakachanov declared that his party and the "Patriots," partners in the ruling coalition, will not support the ratification of the Istanbul Convention, and will fight against it. Karakachanov's discourse repeated a statement published a week earlier by a conservative religious NGO, the Association Society and Values. This NGO was the most active in leading the civil sector in the anti-convention campaign following the political campaign, organizing protests and a petition against ratification, and explaining what the convention means as follows: "The convention implements the definition of gender and gender identity as not depending on biological sex. There are texts which damage seriously and will have dangerous consequences for the rights of women, parents, children, marriage and family, for religious freedom, as well as for national sovereignty, domestic order, security, and migration politics." 17

During the first half of 2018, the bill that was to enshrine the Istanbul Convention into Bulgarian national law met strong opposition from government parties as well as major opposition from the socialist party, the president of the republic, and the Bulgarian Orthodox Church. Manipulative campaigning and deliberate fanning peo- 
ple's fears (of the "third sex," of "gender ideology," and of same-sex marriage) fueled negative popular reactions. In the end, the government withdrew the bill. Prior to its withdrawal, seventy-five members of Parliament (MPs) had asked Bulgaria's Constitutional Court to review the constitutionality of ratifying the convention. On 27 July 2018, the court ruled that the Istanbul Convention contravened the Bulgarian Constitution. The court decision was interpreted as a victory of true Bulgarian Christian values, in defending the common people, the family, and the nation against the global LGBT lobbies and "Brussels' dictate."

In the Czech Republic there are numerous individual researchers and courses dedicated to gender studies at most Czech universities and academic initiatives (some of these almost of a grassroots nature). The Institute of Sociology of the Czech Academy of Sciences has been hosting the research team on "Gender \& Sociology," established in 1990 by Marie Čermáková. The MA program at the Department of Gender Studies at the Faculty of Humanities of Charles University in Prague was accredited in 2004 and is currently subject to reaccreditation. Additionally, the department has just opened a full MA program in gender studies with English as the language of instruction. At Masaryk University in Brno the Department of Sociology until recently offered a dual major BA degree in gender studies (established in 2004), and it continues to offer a specialization in gender studies within an MA program in sociology. As of 2018, the BA degree in Brno ceased to exist.

In a summary evaluation of the circumstances of Czech gender studies institutions published in 2013, Libora Oates-Indruchova has argued that

each of these units has had to face their own struggles motivated by the hostility toward feminist research and suspicions regarding the scientific legitimacy of gender studies on the part of certain institutional structures and powerful individuals within those structures. They are routinely accused of being activists rather than academics and of gender studies having an ideological bent (as if other social sciences did not), and just recently, the commissioned academic evaluators of one of the units expressed the objection to further institutional development of the discipline on the grounds that gender studies was merely a "fashionable" subject of study (that amongst the repeated calls from the political leadership that education needs to respond to the demands of the market). Nevertheless . . . the two Prague teams have established also their public presence as expert resources on issues of gender. ${ }^{18}$

In Brno the official reason given for closing the BA program were student numbers, with reference made to the "lack of interest." In reality, the program in the last couple of years annually had more than 150 applications and between twelve and seventeen incoming students each year. At present some of the faculty formerly teaching in this program within the Department of Sociology remain and continue to teach gender as a specialization within sociology. In Prague, in recent years, critique from within and outside the university, that is, by the media, has become more vocal, describing gender as an ideology rather than as scholarship. More generally, accreditation rules introduced in the Czech Republic have caused some headache for full-fledged gender 
studies programs, since there are new requirements with regard to the number of fulltime senior faculty who must form part of the teaching staff.

In Poland, various universities offer gender studies programs at the graduate level, even though a number of programs have been closed. Graduate programs exist, among others, at the University of Warsaw, the Polish Academy of Sciences, and the Nicolaus Copernicus University in Toruń, and there is also an international cooperation program, the Erasmus Mundus Master's Degree in Women's and Gender Studies GEMMA (mentioned above), at the University of Łódź.

At the same time, "anti-gender" rhetoric is strongly present in Poland. The Polish right reacted vocally to the abolition of the two-year MA program in gender studies in Hungary. Polish rightist media welcomed the idea to "ban gender studies," and engaged in various activities aimed at achieving this goal. One of the MPs of the Law and Justice Party (the ruling party in Poland), Anna Sobecka, in October 2018 initiated a formal interpellation to the minister of science in which she called gender studies "an ideology" and inquired about the number of programs and students, as well as whether the ministry was considering liquidation of gender studies at public universities. So far, no official answer to this interpellation is known. The minister of science, Jaroslaw Gowin, has expressed negative opinions on gender studies in public several times since 2015, when he became minister. Yet he also said in 2016 that he will not interfere in the autonomy of science and academic freedom.

Public initiatives turning aggressively against gender studies in Poland reach back to 2017. At that point, a Polish anti-abortion NGO (the Life and Family Foundation, which at present is led by a major public figurehead of the anti-abortion campaign in Poland) sent a request to public universities in Poland demanding information about the names of academics who teach gender studies, including information about their salaries, and so on. In September 2018, a citizens' petition was launched, addressed to the minister of science, which requested a ban on gender studies. The petition explicitly referred to the policy pursued by Viktor Orbán's Fidesz-led government, and this happened even before the abolition of the two-year MA degree was officially announced in Hungary. The petition has been signed by over thirty thousand people so far.

In 2018, Poland also introduced a higher education reform that involves the reorganization of universities. This law does not affect gender studies directly. Gender studies in Poland are paid studies anyway, financed by the students. More broadly, the higher education reform has been criticized because it affects the status of the social sciences and the humanities. For example, disciplines such as cultural studies and anthropology are no longer recognized and have been replaced by "studies on culture and religion." By contrast, for the time being, research with a focus on gender or involving gender as a category of analysis within the various disciplines, including history, continues to be funded unabatedly through the two major national funding agencies. At many public universities and in the Polish Academy of Sciences formal and informal research groups and centers focusing on or involving gendered approaches are active, and organize events such as conferences and lectures.

This report has not discussed the developments in all Central European countries. Still, in sum it can be said that in many Central and Eastern European countries 
"anti-gender" ideology has made inroads, and it has informed discourse and policies challenging the legitimacy of the academic study of gender. The nationwide ban of MA-level degree studies of gender in Hungary, however, is unprecedented. For the time being much depends, it appears, on collective and individual initiative and action to ensure the continued operation of study programs and modules, and initiate additional activities. In addition, gender studies scholars in many countries have begun to put "anti-gender" ideology under academic scrutiny and to engage in public counter discourse and opposition. They have gone up against the singling-out of particular types of progressive gender policies as harmful to nation, family, and children. They have rejected the connection made between the adherence to progressive "European" gender norms and racist migration policies, and have resisted the association of retrograde gender realities with any particular nation or culture.

In a world where-in guises old or new-aggressive anti-feminism, racism, and blatant politics of social exclusion are gaining ground day by day, any such initiative and intervention counts.

* A large number of scholars from Central and Eastern Europe has collected or provided information for this Editorial Report, among them Krassimira Daskalova, Alexandra Ghit, Isidora Grubacki, Natalia Jarska, Ana Luleva, Libora Oates-Indruchova, Darja Zaviršek, and Susan Zimmermann. Aspasia would like to thank these and all other colleagues who provided information for their contribution. Special thanks go to Susan Zimmermann, who coordinated and framed the whole enterprise.

\section{$\diamond$ Notes}

1. On MATILDA, see https://matilda-european-master.univie.ac.at/ (accessed 10 March 2019). Matilda now is operated by an enlarged Consortium, including the following partners: Université Lumière Lyon 2 as coordinating institution, Universität Wien, Central European University, Sofia University St. Kliment Ohridski, and Università degli Studi di Padova; in addition, Ruhr-Universität Bochum is about to join. On larger debates on women's and gender history, and gender studies, in Central and Eastern Europe and beyond, see the following two discussion forums published in Aspasia: "FORUM. The Birth of a Field: Women's and Gender Studies in Central, Eastern, and Southeastern Europe," edited and with a conclusion by Krassimira Daskalova, Parts I and II, Aspasia: The International Yearbook of Central, Eastern, and Southeastern European Women's and Gender History 4 (2010): 155-205 and 5 (2011): 128-203; and "FORUM. Clio on the Margins: Women's and Gender History in Central, Eastern, and South Eastern Europe," edited and with an introduction by Krassimira Daskalova, Parts I and II, Aspasia, 6 (2012): 126-185; and 7 (2013): 132-213.

2. For an analysis of this episode and recent "anti-gender" trends and relevant "reforms" of the educational system in Hungary, see Erzsébet Barát, "Revoking the MA in Gender Studies in Hungary Enmeshed in the Right-Wing Populist Political Rhetoric," forthcoming in L'Homme: Europäische Zeitschrift für feministische Geschichtswissenschaft [L'Homme: European journal for feminist historical sciences] 30 (2019): 2.

3. Ana Kolarić and Biljana Dojčinović, eds., Feministički časopisi u Srbiji: Teorija, aktivizam $i$ umetničke prakse u 1990-tim i 2000-tim [The feminist press in Serbia: Theory, activism and art 
practices in the 1990s and 2000s] (Filološki fakultet Univerziteta u Beogradu: Beograd, 2018), http://doi.fil.bg.ac.rs/volume.php?l=rsl\&pt=eb_book\&y=2018\&issue=femjis-2018\&i=0 (accessed 15 March 2019).

4. PATTERNS Lectures is a program to support the development of new university courses in Central and Southeastern Europe. PATTERNS Lectures was initiated by ERSTE Foundation and is being implemented by World University Service (WUS) Austria. "Serbia": http:// patterns-lectures.erstestiftung.net/20162017-2/selected-courses/\#eindeutiger-bezeichnerVII (accessed 12 March 2019).

5. The incident is documented in Darja Zaviršek and Barbara Rajgelj, "Anti-refugee Sentiment without Refugees: Human Rights Violations and Social Work in Post-socialist Countries of Southeastern Europe in their Social Contexts," Journal of Human Rights and Social Work 4, no. 1 (2019): 5-17, http://link.springer.com/article/10.1007/s41134-018-0083-2 (accessed 5 April 2019).

6. Amir Hodžić and Aleksandar Štulhofer, "Embryo, Teddy Bear-Centaur and the Constitution: Mobilizations against 'Gender Ideology' and Sexual Permissiveness in Croatia," in Anti-gender Campaigns in Europe: Mobilizing Against Equality, ed. Roman Kuhar and David Paternotte (Lanham, MD: Rowman \& Littlefield, 2017), 59-77; Zaviršek and Rajgelj, "Anti-refugee Sentiment without Refugees."

7. Darja Zaviršek, Skrb kot nasilje [Care as violence] (Ljubljana: /cf*, 2018).

8. See, e.g., her contributions in Jelena Jovanović, Angéla Kóczé, Enikő Vincze, and Violetta Zentai, eds., The Romani Women's Movement: Struggles and Debates in Central and Eastern Europe (London: Routledge, 2018).

9. Original call for papers: https://blacksea-horizon.eu/object/event/947/attach/Queer Fem_SEE_Call_for_Papers.pdf (accessed 14 March 2019). Proceedings from the conference will be published here: http://feminist.krytyka.com/en/issues/feminist-critique-2-2019 (accessed 12 March 2019).

10. http://www.analize-journal.ro/issue-no-10-242018 (accessed 14 March 2019).

11. https://www.amosnews.ro/scrisoare-deschisa-reprezentantilor-mediului-academic-refe ritoare-la-prolematica-egalitatii-de-genhttps://www.amosnews.ro/scrisoare-deschisa-reprezentantilor-mediului-academic-referitoare-la-prolematica-egalitatii-de-gen (accessed 14 March 2019).

12. https://www.amosnews.ro/scrisoare-deschisa-reprezentantilor-mediului-academic-refe ritoare-la-prolematica-egalitatii-de-gen (accessed 14 March 2019).

13. The earlier development of gender studies in Bulgaria is documented in Ana Luleva, "Zum Stand der Geschlechterforschung in Bulgarien" [The state of the art in gender studies in Bulgaria], in EU-Bulgaristik:Perspektiven und Potentiale [Bulgarian studies in the EU: Perspectives and potentials], ed. Christian Voß (Berlin: Verlag Otto Sagner, 2009), 161-171.

14. A detailed analysis is given in Ana Luleva, "Pride and Prejudices: Gender in the Focus of the Emotional Public Discourse in Bulgaria," paper presented at the $9^{\text {th }}$ In ASEA conference "Emotions, Senses, and Affect in the Context of Southeast Europe," Zadar, Croatia, 27-30 September 2018.

15. https://trud.bg;https://offnews.bg/obshtestvo/avtorite-na-proekta-za-dzhendar-modelv-uchilishte-nalozhiha-ni-tcenz-685661.html (accessed 12 March 2019).

16. http://glasove.com/categories/intervyuta/news/vmro-mezhdunarodni-lobita-natiskat-by lgariya-da-uzakoni-tretiya-pol (accessed 19 March 2019).

17. http://legalworld.bg/67724.vmro-se-obiavi-sreshtu-ratificiraneto-na-istanbulskata-kon venciia-podpisana-ot-ekaterina-zaharieva.html; http:/glasove.com/categories/na-fokus/news/ istanbulskata-konvenciya?page $=2$ (accessed 12 March 2019).

18. Libora Oates-Indruchova, "The Local and the Global in Czech Gender Studies," NewsNet: News of the Association for Slavic, East European, and Eurasian Studies 53, no. 4 (2013): 1-3. 